\title{
Antecedents and Outcomes of Innovation-Oriented Cultures
}

\author{
Dawn De Tienne ${ }^{1} \&$ Paul Mallette ${ }^{1}$ \\ ${ }^{1}$ Department of Management, College of Business, Colorado State University, CO, USA \\ Correspondence: Paul Mallette, Department of Management, College of Business, Colorado State University, \\ Fort Collins, CO 80523, USA. Tel: 1-970-491-5172. E-mail: paul.mallette@colostate.edu
}

Received: June 11, 2012 Accepted: August 6, 2012 Online Published: September 16, 2012

doi:10.5539/ijbm.v7n18p1 URL: http://dx.doi.org/10.5539/ijbm.v7n18p1

\begin{abstract}
This research investigates the relationships between innovation antecedents and innovation-oriented cultures. In addition, it explores the relationship between innovation-oriented cultures and performance outcomes. Our findings from 192 CEOs across three industries indicate that risk orientation, R\&D expenditures, intra-firm linkages, improvisation and experimentation are related to innovation-oriented cultures. In addition, innovation-oriented cultures contribute to product innovation and have a significant impact on a firm's growth and performance.
\end{abstract}

Keywords: innovation, innovation culture antecedents, innovation culture, innovation outcomes

\section{Innovation - An Overview}

The belief that businesses should pursue innovation is widely accepted by both practicing managers and organizational scholars. While the most commonly assumed benefit of innovation is improved financial performance (Deal \& Kennedy, 1982; Sorenson, 2002), others include expanding markets (Bussey, 2012; Korth, 2005), enhanced brand and a way to differentiate the business (Peace, 2011), faster adoption rates and making work fun (Needleman et al., 2011), better customer alignment and improved efficiency (Brynjolfsson \& Schrage, 2009), a way to diversify and adapt to environmental change (Spencer, 2012), and a means to achieve long-term competitive advantage and increased company value (Herring \& Galagan, 2011). While the notion that firms must pursue innovation is not controversial, it is one of the most complex and difficult processes in which organizations are engaged and results vary greatly across companies (More, 2011). The fundamental question of why some organizations are more successful at innovation than others is one that is both important and worthy of critical examination.

Much of the extant literature has focused on innovation from the perspective of the individual. However, several studies have examined the internal and external environmental factors that foster it. External factors that have been linked to innovation include the economic environment (Damanpour \& Schneider, 2006), competition and market conditions (Kaiserfeld, 2005), technology (Brynjolfsson, \& Schrage, 2009), government actions (More, 2011), industry life cycle stage (Utterback \& Abernathy, 1975), environmental dynamism (Koberg, DeTienne, \& Heppard, 2003) and environmental uncertainty (McGinnis \& Ackelsberg, 1983).

Internal factors linked to innovation include the organizations' structure and processes (Damanpour, 1991; Damanpour, 1996), organizational size (Damanpour, 1996; Damanpour \& Schneider, 2006; Koberg, et al., 2003), organizational knowledge and information (Cowan \& Jonard, 2003), and organizational complexity, organizational size, and top management education (Damanpour \& Schneider, 2006).

While these factors have been shown to differentially impact innovation, research on the impact of innovation-oriented cultures on innovation outcomes has received little research attention. Burgelman (1986) suggests that innovation results from the innovative behavior of organizational members when leaders create an environment in which desired actions can take place. Van de Ven (1986) recognizes that innovation results from a network of personal and group interactions. In organizations these interactions are shaped, to a large degree, by organizations' cultures that support the activity. Further, the link between innovation and culture is supported through organizational structures that are considered to be organic (Torenatzky et al., 1983). Kimberly (1981) argues that innovation relies on the receptivity to change that exists within the organization. This view clearly indicates the central role that culture plays in innovation. Further, it has been suggested that innovation requires a context in which the beliefs encouraging and supporting innovation as a necessary adaptive response to 
environmental change become ingrained (Russell \& Russell, 1992) and that this perspective must permeate the entire organization Damanpour (1991). And yet, little has been done to move beyond the study of strategies and structures suitable for innovation, even though there is evidence that innovation is better explained by the general work environment than by strategies and structures alone. Often little or no account is taken of the social environment within which innovation occurs (Chatman \& Jehn, 1994).

\section{Theoretical Perspectives}

Several theoretical perspectives have been employed to examine innovation. Perspectives that support the current study include actor-network theory, neo-classical economic theory, institutional theory, and the theory of social construction of technology. Actor-network theory posits that innovations need engagement from different actors individual and organizational. These actors are engaged through networks. Some of these networks are global (containing resources such as market, engineering, or scientific information) and some are local to the firm. The theory suggests that as more resources are obtained from the global network, the probability of successful innovation increases (Latour, 1996). The realization that networks are fundamental to innovation is an important factor that shapes managers' risk taking propensity and organizational processes.

Neo-classical economic theory also recognizes the role of external forces in innovation. The main economic force is the market, in which competition between firms drives innovation. From this perspective innovation is seen as necessary to provide value to customers while simultaneously allowing innovators to generate profit. Institutional theory is a logical extension of the theory in that innovations that help the organization adapt to dynamic environmental conditions are often viewed as necessary. Institutional forces may impede change but they can also initiate it. For example, when a company develops a change that is deemed successful, the change is likely to be mimicked by other organizations (Haunschild \& Miner, 1997). As other organizations copy the successful innovation, it becomes institutionalized because it is viewed as a form of legitimacy. Processes, routines, and cultures are all examples of organizational adaptations that can lead to desirable outcomes that may be imitated by competitors.

The theory of social construction of technology (TSCOT) views innovation as the result of social processes in which groups seek to encourage certain innovations over others. An innovation with support from relevant social groups will be adapted and used (Bijker, Hughes, \& Pinch, 1989). According to Barker (1999), organizational culture is a discursive formation of knowledge (identified here as managerial and organizational factors and processes - what the organization does) designed to create useful meanings. These actions fit within TSCOT.

Taken together, these perspectives explain innovation as the result of internal and external forces. These forces shape managerial and organizational dimensions that result in innovation-oriented cultures and, subsequently, firm performance. The theories discussed above help explain some of the key factors that underlie innovation. As such, they are useful in identifying the variables and research hypotheses that are used in the current study.

\section{The Model}

The model that guided this research is presented in Figure 1. We examine the relationships among risk orientation, investments in research and development (R\&D), scanning and search processes, and decisions as to how to structure the organization (intrafirm linkages) as well as on two innovative processes (experimentation and improvisation) that create a culture and momentum for change and innovation for managers of firms with multiple successful innovations (Brown \& Eisenhardt, 1998; Koberg, et al., 2003) and innovation-oriented culture. Last, we investigate the effects of an innovation-oriented environment on three outcome measures - product innovation, firm growth, and return on investment (Brush \& Vanderwerf, 1992; Dess \& Robinson, 1984; Ziger \& Maidique, 1990).

Our model suggests that innovative outcomes and firm performance from one period affect managerial decisions and behaviors, and culture in subsequent periods (designated by dotted lines). Culture is largely a matter of norms (Barker, 1999; Kilman 1985; Sorensen, 2002). Norms, comprise the collective habits, customs, and informal rules which determine how work is done, and how people relate to one another in uncertain situations such as innovation, which involves considerable uncertainty and change. Norms, which are fairly resistant to short-term pressures, comprise "a relatively coherent and consistent set of beliefs and prescriptions governing the behavior of participants" that are widely shared and strongly held throughout the organization (O'Reilly \& Chatman, 1996: 1666). They are the means by which managerial beliefs are expressed and transmitted, and involve "those overarching 'shalts and shalt nots' which govern the actions or behaviors, imply the sanctions, and in time permeate the souls of organization members" (Cabrera \& Bonache, 1999: 54). 


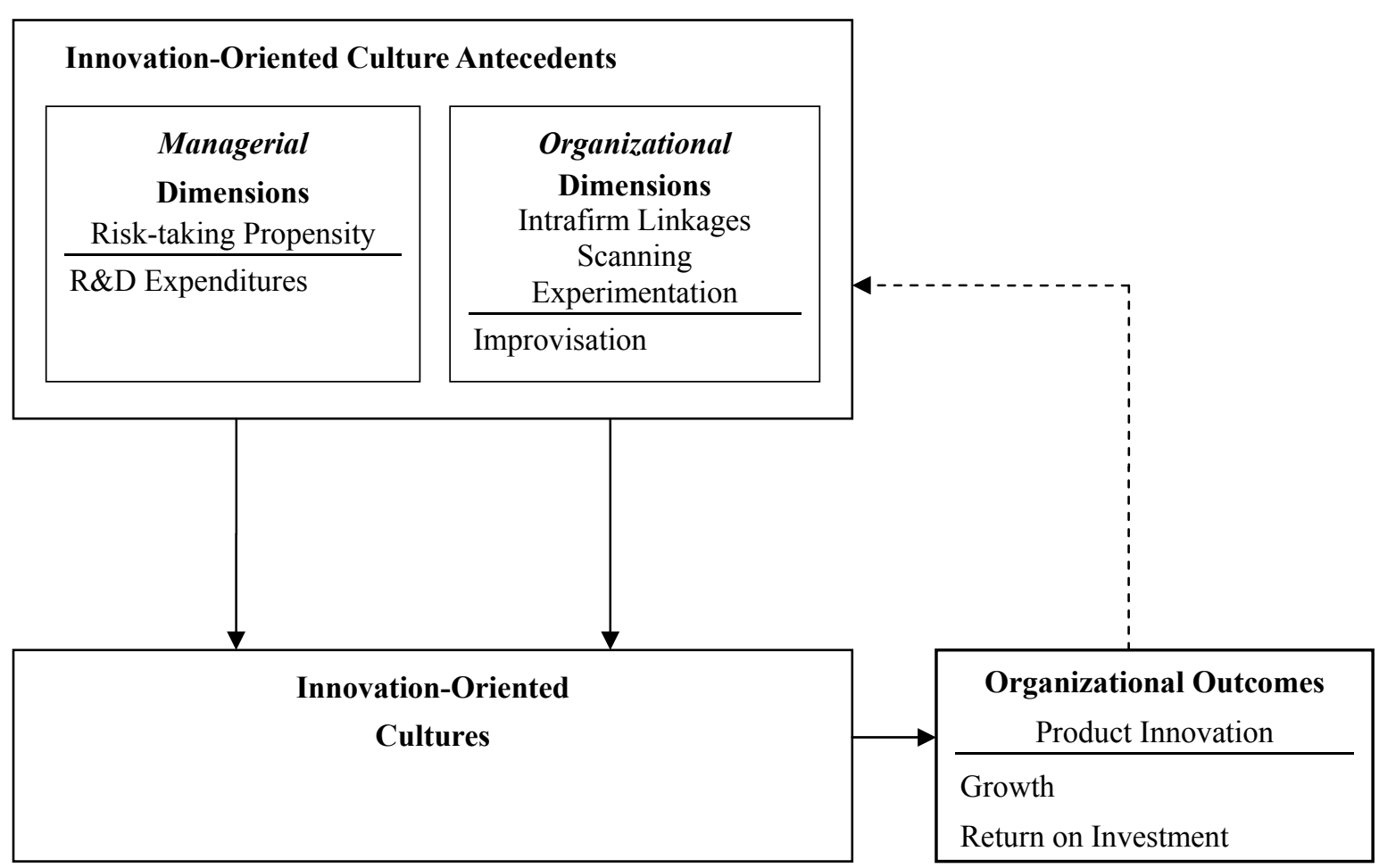

Figure 1. Model of cultural antecedents, innovation-oriented cultures, and organizational outcomes

\section{Research Hypotheses}

\subsection{Managerial Factors}

\subsubsection{Risk Taking}

Researchers with the Minnesota Innovation Research Program (MIRP) reported that top managers who were responsible for biomedical innovations considered risk taking necessary to long-term viability and growth of the corporation (Van de Ven, et al., 1999). A work environment that supports risk-taking enhances innovation and creativity (Amabile, 1997; Woodman, Sawyer, \& Griffin, 1993). However, managers have finite resources to allocate, and differ in their willingness to take risks on unproven ideas (Chiesa, Coughian, \& Voss, 1996, Oster, 1994). The further away a new innovation is from the old, the greater the technical, market, and competitive uncertainty, and the greater the risk (Oster, 1994; Sykes \& Block, 1989).

\subsubsection{R\&D Expenditures}

Our model suggests that R\&D spending promotes an innovation-oriented culture. Research on innovation shows a positive relationship between resource availability and innovation (e.g., Damanpour, 1991). In order for there to be innovative output, there must be some innovative input or investment in R\&D (Oster, 1994).

Hypothesis 1a: Top managers will positively relate risk taking with innovation-oriented cultures.

Hypothesis 1b: Top managers will positively relate research and development expenditures with innovation-oriented cultures.

\subsection{Intrafirm Linkages, Scanning Processes, Experimentation and Improvisation}

\subsubsection{Intrafirm Linkages}

Not only do structural aspects (intrafirm linkages) of a firm foster a work environment favorable to innovation, but they themselves are influenced by the nature of the work environment. Though not all innovation occurs through joint action, bringing a new product/service from concept to development typically requires the collaborative efforts of a group of people with specialized knowledge in a variety of fields concurrently working on different aspects of a project (Brown \& Eisenhardt, 1997; DeTienne \& Koberg, 2002; Kessler \& Charkrabarti, 1996; Koberg, et al., 2003; Scott \& Bruce, 1996). Intrafirm linkages create cross-functional integration and an open exchange of information within the firm (Russell \& Russell, 1992). 


\subsubsection{Scanning and Search Processes}

Because new ideas and ways of doing things are embedded both outside and inside the organization, managers need to gather information about external trends and events that may be forerunners of significant opportunities for change and innovation (Delaney, Jarley, \& Fiority, 1996). Environmental scanning or "knowledge acquisition through searching" occurred early in the innovation process (Van de Ven, et al, 1999: 83). Koberg, Uhlenbruck, and Sarason (1996), in a study of high technology firms, reported that scanning predicted product innovation among both early and late stage firms. Thus, managers actively search for innovative ideas from outside the organization that might be applied by the organization.

\subsubsection{Experimentation and Improvisation}

Two organizational processes that build in organizational flexibility (strategic responsiveness) and help create an organizational culture of change and innovation are experimentation and improvisation. The more companies practice experimentation and improvisation, the better they do it and the more ingrained the practices become (Leonard, 1995). Previous research has shown experimentation to be positively related to radical innovation (defined as the creation of new major product/service programs leading to expansion of current markets) (Koberg, et al. 2003); however little empirical evidence is available about the link with the firm's innovation oriented culture. Both processes imply trial and error learning. Managers who experiment attempt to gain insight into the future. Managers who improvise must balance structure, budgets, and schedules with flexibility. They know what to structure and what not to structure, given the uncertain requirements of innovation. Clearly some coordination is required, but too much or too tight coordination impedes the ability to innovate.

Hypothesis 2a: Top managers will positively relate intrafirm linkages with innovation-oriented cultures.

Hypothesis 2b: Top managers will positively relate scanning and search processes with innovation-oriented cultures.

Hypothesis 2c: Top managers will positively relate experimentation with innovation-oriented cultures.

Hypothesis 2d: Top managers will positively relate improvisation with innovation-oriented cultures.

\subsection{Product Innovation and Performance}

A central argument of this study has been the notion that an innovation-oriented culture represents a potentially valuable factor that strengthens our understanding of the determinants of product innovation and subsequent firm performance. The criteria for evaluating the success or failure of an innovation shift over time; nevertheless, top managers are accountable for achieving performance targets. Although there are many alternative measures of performance, efficiency, growth, and profit are the most commonly considered dimensions (Brush \& Vanderwerf, 1992; Murphy, Trailer \& Hill, 1996), Entrepreneurial behavior (with its underlying theme of innovation) is shown to lead to superior firm performance, as measured by growth and profitability (Covin and Miles, 1999: 47; Zahra and Covin, 1995). In this study we measure firm performance through firm growth (as measured by change in employees) and profitability (as measured by ROI).

H3a: Top managers will positively relate innovation-oriented cultures to product innovation.

H3b: Top managers will positively relate innovation-oriented cultures to organizational growth.

H3c: Top managers will positively relate innovation-oriented cultures to organizational profitability.

\section{Methods}

\subsection{Sample}

\subsubsection{Organizations and Executives}

The data for this study is part of a larger study of innovation. The sample frame for this study was selected from Ward's Business Directory of U.S. Private and Public Companies. Ward's Directory contains a complete list of public companies and is also a leading source of information about companies that are not publicly traded or are subsidiaries of larger companies ( $90 \%$ of which are private). To select the sample frame we used a two-step approach. First, we selected three industry strata: (1) aerospace (SIC 336411 through 336415, and 336419); (2) electronic components and superconductors (SIC 334415 through 334419); and (3) telecommunications (SIC 513321,513322 , and 51331 through 51333). We then randomly selected samples of 300, 350, and 250, respectively, from each of the three industry strata, for a total of 900 firms. These industries have all experienced rapid technological progress and innovation.

In accordance with the Total Design Method (TDM) described by Dillman (1978), we mailed questionnaires, accompanied by postpaid return envelopes and cover letters, to the chief executives (chairman, CEO, and 
president) of the 900 firms in the sample frame. A reminder letter with a replacement survey questionnaire was mailed three weeks after the initial mailing.

We obtained response rates of $24.3 \%, 23.7 \%$, and $14.8 \%$, respectively, for the aerospace, electronic components, and telecommunications industries. These response rates are consistent with Stimpert's (1992) report that in studies using chief executives as addressees, response rates range from $14 \%$ to $34 \%$.

\subsubsection{Interviews}

We conducted semi-structured interviews of a total of twenty-five executives from the three industries who volunteered to talk with us, and who gave us leeway to elaborate on our questions. The executives we interviewed were senior managers, as evidenced by their position, age, time in the job, and time with the company. They had major responsibility for firm performance, including research and development, sales and marketing, and production and manufacturing. We conducted extensive semi-structured interviews to help generate descriptive indicators of norms for innovation, to avoid misrepresentation or misinterpretation of the results from the questionnaire data, and to help strengthen the results of the quantitative analyses. The interviews were conducted on the telephone or in person and lasted between 30 and 40 minutes. All interviews were taped and transcribed. We were convinced that the interviews captured responses that were representative of the larger sample frame based on interviews with a small number of nonrespondents. In accordance with the principles of theoretical sampling (Miles \& Huberman, 1994), we limited the number of interviews when we knew we were repeatedly hearing the same themes from our interviewees.

\subsection{Measures}

We employed scales that had been had been standardized and validated by other researchers (e.g., Brown \& Eisenhardt, 1998; Koberg, et al. 2003; Russell \& Russell, 1992). A pilot study with a small number of executives from each industry showed that the scale items selected generally had relevance in terms of their face validity, and fit with our a prior dimensions of an innovation-oriented environment and product innovation. Composite measures were computed by averaging the unweighted mean scores on the individual scale items.

\subsubsection{Innovation Norms}

Rousseau (1990) suggested that the more observable, available elements of culture, such as behavioral norms, favor "a quantitative and thus comparative methodological approach" (Cabrera \& Bonache, 1999: 54). We measured norms favoring innovation using eight Likert scaled items adapted by Russell and Russell (1992) from Zaltman, Duncan, and Holbek (1973). We obtained a reliability coefficient of .87. The items were factor analyzed, employing a varimax rotation, and all 8 items loaded significantly on one common factor with an eigen value of 4.35 , and loadings ranging from .46 to .82 .

\subsubsection{Risk Taking}

We measured propensity toward risk taking by two items developed by Miller and Friesen (1982). We obtained a reliability coefficient of .69, one identifiable factor (Eigen value of 1.53), and loadings of .76 and .76.

\subsubsection{R\&D Expenditures}

R\&D expenditures were operationalized as average annual research and development spending (as a percentage of sales).

\subsubsection{Scanning and Search Processes}

We measured the frequency of scanning and search processes using a five item 5-point Likert scale adapted from the work of Miller and Friesen (1980). We obtained an alpha coefficient of .79, a single common factor with an Eigen value of 2.79 , and factor loadings of $.52, .70, .84, .83$, and .78 .

\subsubsection{Intrafirm Linkages}

We measured intrafirm linkages using eight 5-point Likert items based on research by Brown and Eisenhardt (1998) and Muffatto and Panizzolo (1996). We obtained a reliability coefficient of .78, and one identifiable factor (Eigen value of 3.07) with loadings ranging from .42 to .80 .

\subsubsection{Experimentation and Improvisation}

To measure experimentation and improvisation we adapted a group of paired statements (separated a 5-point Likert scale) developed by Brown and Eisenhardt (1998). The experimentation measure consisted of seven paired statements. We factor analyzed these items, using principal component analysis with varimax rotation. One item, reflecting whether success of a firm depended on one industry scenario, had a weak loading (less than .40) on the first factor and a low item-total correlation, and therefore had to be deleted from the scale. The 
following remaining six items had an alpha coefficient of .80, Eigen value of 3.05, and factor loadings from .60 to .81 . The measure of improvisation originally had eleven paired statements. We deleted five items with weak loadings (less than .40) on the first factor and low item-total correlations. The remaining six items had an alpha coefficient of .74, Eigen value of 2.70, and loadings from .50 to .81 .

\subsubsection{Product Innovation}

The research indicates many measures of organizational innovation, however, no standardized measures exist. In this study we use top manager's perception of innovation employing three paired statements developed by Miller and Friesen (1982) to measure innovation in product lines, services, and programs. Though some researchers question the validity of studies using self-report data, Khan and Manichetwatana (1989) and Jennings and Young (1990) reported a strong correlation between perceptual and objective measures of innovation. In addition, the respondents (top managers) are best positioned to be able to provide a snapshot of innovation within their organization. We obtained an alpha coefficient of .74, one identifiable factor with an Eigen value of 2.02, and factor loadings ranging from .68 to .88 .

\subsubsection{Growth and Profitability}

Measures of performance are routinely criticized. Our choice of growth and profitability as performance measures is supported by Dess and Robinson (1984: 271) and Murphy, et al. (1992). We operationalized growth as the change in number of employees over the last 3 years. We operationalized profitability as return on investment over the last 3 years.

\subsection{Analysis and Results}

The means and standard deviations of each scale, together with the bivariate relationships (correlations) among the variables (without controlling for the effects of other variables), are given in Table 1. The bivariate results generally conformed to empirical and theoretical expectations. Predictably, experimentation and improvisation positively correlated with each other, as did growth (in sales) and profitability (ROI). Unexpectedly, risk taking and $R \& D$ were unrelated to each other although both positively related to scanning and search processes.

Table 1. Means, standard deviations, and zero order correlations

\begin{tabular}{lcccccccccccc}
\hline Variables & \multicolumn{1}{c}{ Mean } & S.D. & \multicolumn{1}{c}{ Zero Order Correlations } & \\
\hline & & & 1 & 2 & 3 & 4 & 5 & 6 & 7 & 8 & 9 & 10 \\
1. Innovation Norms & 3.69 & 0.67 & - & & & & & & & & \\
2. Risk Orientation & 2.77 & 0.88 & $.17^{*}$ & - & & & & & & & \\
3. R\&D Expenditures & 1.78 & 0.99 & $.25^{* *}$ & 0.12 & - & & & & & & \\
4. Scanning and Search & 13.52 & 3.39 & 0.02 & $.19^{* *}$ & $.14^{* *}$ & - & & & & & \\
5. Intrafirm Linkages & 3.54 & 0.62 & $.38^{* *}$ & 0.11 & $.20^{* *}$ & $.39^{* *}$ & - & & & & \\
6. Experimentation & 3.46 & 0.69 & $.36^{* *}$ & $.20^{* *}$ & $.15^{*}$ & $.36^{* *}$ & $.43^{* *}$ & - & & & \\
7. Improvisation & 3.59 & 0.55 & $.31^{* *}$ & $.01-$ & 0 & $.20^{* *}$ & $.33^{* *}$ & $.56^{* *}$ & - & & \\
8. Product Innovation & 3.51 & 0.99 & $.22^{* *}$ & $.30^{* *} .27^{* *}$ & $.37^{* *}$ & $.32^{* *}$ & $.44^{* *}$ & 0.19 & - & \\
9. ROI & 3.42 & 1.25 & 0.14 & -0.01 & 0.05 & $.15^{*}$ & 0.08 & $.22 * *$ & 0.13 & 0.13 & - \\
10. Growth & 2.61 & 1.106 & $.15^{*}$ & $.27^{* *} .31^{* *}$ & 0.13 & 0.04 & $.20^{* *}$ & -0.02 & $.34^{* *}$ & $.32^{* *}$ & - \\
\hline
\end{tabular}

$* \mathrm{p}=.05 ; * * \mathrm{p}=.01$

We performed one-way analysis of variance (ANOVA) to determine whether we should control for the effects of industry in tests of the research hypotheses. We found no significant industry effects in the research variables by industry with one exception. The growth rate in sales over the last 3 years was higher for telecommunications $(\mathrm{M}=3.61)$ than for electronics $(\mathrm{M}=3.09)$ or aerospace firms $(\mathrm{M}=2.96)(\mathrm{F}=3.65, \mathrm{DF}=2,181, \mathrm{p}=.03)$. Because we found no other industry differences in the research variables, for purposes of hypotheses testing, we aggregated data across the three industries.

Although the standard deviations of the research variables are smaller for some variables (for example, improvisation) than for others (for example, risk taking), regression coefficients are not affected by range 
restriction when assumptions of linearity and homoscedasticity are met (Cohen, 1988). We used hierarchical regression to assess the effects of norms for innovation on managerial factors (risk orientation and R\&D expenditures) and organizational processes (scanning and search processes, intrafirm linkages, experimentation, and improvisation). We used MANCOVA to assess the effects of an innovative culture on organizational outcomes (product innovation, growth and ROI). MANCOVA allows the simultaneous testing of the effects of the predictor variables on two or more dependent variables.

Hypotheses $1 \mathrm{a}$ and $1 \mathrm{~b}$ related risk taking propensity and R\&D expenditures to innovation-oriented cultures (as measured by organization norms). Table 2 shows that both variables were significant predictors of an innovation-oriented culture. Hypothesis $2 \mathrm{a}, 2 \mathrm{~b}, 2 \mathrm{c}$, and $2 \mathrm{~d}$ related intrafirm linkages, scanning and search processes, experimentation and improvisation, respectively, to innovation-oriented cultures. Intrafirm linkages, experimentation and improvisation were significant predictors of an innovation-oriented culture, thus supporting hypotheses $2 \mathrm{a}, 2 \mathrm{c}$ and $2 \mathrm{~d}$. There was no support for hypothesis $2 \mathrm{~b}$.

Hypotheses $3 \mathrm{a}, 3 \mathrm{~b}$, and $3 \mathrm{c}$ related innovation-oriented cultures to product innovation, growth, and profitability, respectively. The MANCOVA produced one significant multivariate effect (Wilk's Lambda $=.51, \mathrm{p}=.003$ ). The results of performing analysis of variance and Scheffe's multiple-comparison

Technique with a .01 alpha level revealed that an innovation-oriented culture was a significant positive predictor of product innovation, growth and ROI. Hypotheses $4 \mathrm{a}, 4 \mathrm{~b}$, and $4 \mathrm{c}$ were thus supported. After removing the effects of the managerial and organizational factors and processes, an innovation-oriented culture accounted for $34 \%$ of the variance in product innovation (Adj. $\mathrm{R}^{2}=.342$ ); $14.5 \%$ of the variance in growth (Adj. $\mathrm{R}^{2}=.211$ ) and $12 \%\left(\right.$ Adj. $\mathrm{R}^{2}=.123$ ) of the variance in ROI.

Table 2. Results of the hierarchical regression

\begin{tabular}{lll}
\hline Variables & Model 1 & Model 2 \\
\hline Risk Orientation & $.14^{*}$ & \\
$\mathrm{R} \&$ D Expenditures & $.23 * *$ & \\
Scanning \& Search & & $-.24^{* *}$ \\
Intrafirm Linkages & & $.30^{* * *}$ \\
Experimentation & & $.16^{*}$ \\
Improvisation & & $.17^{*}$ \\
$\mathrm{~F}$ & 8.21 & 11.99 \\
$\mathrm{R}^{2}$ & 0.08 & 0.28 \\
$* \mathrm{p}=.05 ; * * \mathrm{p}=.01 ; * * * \mathrm{p}=.001$ &
\end{tabular}

The statistical power of the tests was checked to determine the possible effect of sample size on the findings. On the basis of a conventional medium-size effect, as indicated by a population $\mathrm{r}$ of .30 (Cohen \& Cohen, 1983; Cohen, 1988), we determined the odds that a test would be significant to be .81 . This value exceeds the acceptable significant value of .80 indicated by Cohen and Cohen (1983), and suggests that the size of the study's sample did not significantly bias the findings.

\section{Discussion and Conclusions}

Our study makes several important contributions to the literature on innovation. First, while scholars differ about whether managerial (e.g., risk taking) or organizational (e. g., intrafirm linkages) factors are the most powerful or important in explaining innovation, the results of this study suggest that cultural forces appear at least as important as other factors in predicting product innovation. Second, findings suggest that chief executives who reported innovation-oriented cultures favored risk taking and were more likely to expend resources on R\&D. Third, this study supports arguments by Brown and Eisenhardt $(1997,1998)$ that managers of firms with cultures of innovation, openness, and change tend to improvise and experiment and form intrafirm linkages. Fourth, notwithstanding the casual determinacy of knowing whether cultural forces are a consequence rather than a cause of product innovation, the present study is in keeping with suggestions by other researchers that innovation-oriented cultures are associated with increased product innovation (Busentiz \& Lau, 1996; Klein \& Sorra, 1996), growth and profitability. These findings are significant when one considers that the effects of the 
managerial and organizational factors were removed and we directly examined the relationship between innovation-oriented cultures and firm performance.

Top managers develop an ideology and orientation toward risk taking, whether implicit or explicit, which influences (and is influenced by) organizational norms (Chiesa, Coughian, \& Voss, 1996). In innovation-oriented environments, top managers not only are oriented toward risk taking but also are more likely to expend resources on research and development. Not all managers are able to commit resources to R\&D, and those who fail embrace an ideology of risk taking and invest in $R \& D$ are at a relative disadvantage in developing innovations.

Our finding that scanning and search processes were negatively related to an innovation-oriented culture was unexpected. However, we focused solely on formalized scanning and search processes (e.g., explicit tracking of the policies and tactics of competitors and suppliers; market research studies; formalized evaluation of opportunities for new acquisitions, investments, and markets; and formalized evaluation of threats from competitors and regulatory changes). Perhaps managers depend more on informal ones.

Our finding that, top managers form intrafirm linkages in innovation-oriented environments is consistent with prior research (Brown \& Eisenhardt, 1997, 1998; DeTienne \& Koberg, 2002; Koberg, et al. 2003). Cross-functional linkages within an organization require little effort or cost to adopt, and serve to hold teams of individuals together by cutting across projects and product groups.

The finding that innovation-oriented cultures are related to product innovation is not surprising. However, an important finding in this area was the relationship between innovation-oriented cultures and firm performance. Many have suggested that it takes a long time and may not even be possible to create an innovative culture which leads to increased performance. Across the three industries examined in this study we believe this is not the case.

While we believe the findings in the current study make a significant contribution to the literature, some possible limitations need to be addressed. The findings are limited by difficulties inherent in disentangling cause and effect in our cross-sectional analysis - although, we did use qualitative data to help confirm our quantitative findings. The present study suggests that norms favoring innovation predict product innovation, rather than the reverse, although innovation outcomes can be "both a cause and consequence of action" (Van de Ven, et al., 1999: 12). In addition, findings are limited by the difficulties inherent in drawing generalizations from three industries. Future researchers should examine diverse samples since different organizations and industries would be expected to have different cultures.

Future research is indicated to investigate how and to what degree top managers influence cultural forces within their organizations. Future research could also address how and to what degree forces outside managerial control (such as environmental forces including a host of market, social, economic, competitive, and technological factors) influence cultural forces. Another area that remains to be addressed is how organizational subcultures impact innovation outcomes (Hopkins, Hopkins, \& Mallette, 2005). Subcultures exist when the norms of groups within the organization differ from each other and those that top management espouse.

Our findings also have implications for practicing managers. Managers must be aware of the variety of activities and approaches available to practitioners who wish to encourage a culture of change and innovation within their organizations. For example, there are a variety of activities available to practitioners who wish to encourage experimentation and improvisation within their organizations, including brainstorming, prototyping, and scenarios. Further, evidence presented herein can help managers make the business case for why an innovation-oriented culture matters and which factors help establish it.

Innovative companies continue to push existing boundaries in many different ways. Culture is likely to have a profound and continuing effect on innovation within organizations, contributing to the development of different norms, habits, and ways of working. An innovation-oriented culture appears to be extremely important in predicting future innovation and, subsequently, organizational performance.

\section{References}

Amabile, T. M. (1997). Motivating creativity in organizations: On doing what you love and loving what you do. California Management Review, 40(1), 39-57.

Barker, J. (1999). Reading organizational culture as generative discipline: The discipline of teamwork. Thousand Oaks, CA.: Sage.

Bijker, W. E., Hughes, T. P., \& Pinch, T. (1989). The Social Construction of Technological Systems. MIT Press: 
Cambridge, MA.

Brown, S. L., \& Eisenhardt, K. M. (1997). The art of continuous change: Linking complexity theory and time-paced evolution in relentlessly shifting organizations. Administrative Science Quarterly, 42, 1-34. http://dx.doi.org/10.2307/2393807

Brown, S. L., \& Eisenhardt, K. M. (1998). Competing on the edge: Strategy as structured chaos. Boston: Harvard Business School.

Brush, C., \& Vanderwerf, P. (1992). A comparison of methods and sources for obtaining estimates of new $\begin{array}{llll}\text { venture performance. Journal of } & \text { 157-170. }\end{array}$ http://dx.doi.org/10.1016/0883-9026(92)90010-O

Brynjolfsoon, E., \& Schrage, M. (2009). The new, faster face of innovation: Thanks to technology, change has never been so easy or so cheap. The Wall Street Journal, August 17, R. 3.

Burgelman, R. (1986). Managing corporate entrepreneurship: New structures for implementing technological innovation. In M. Horwitch (Ed.), Technology and the Modern Corporation (pp. 112-153). New York: Pergamon Press.

Busentiz, L. W., \& Lau, C. M. (1996). A cross-cultural model of new venture creation. Entrepreneurship Theory \& Practice, 20(4), 25-39.

Bussey, J. (2012). The Anti-Kodak: How a U.S. firm innovates and thrives. Wall Street Journal Online, January 13.

Cabrera, E., \& Bonache, J. (1999). An expert HR system for aligning organizational culture and strategy. Human Resource Planning, 22(1), 51-60.

Chatman, J. A., \& Jehn, K. A. (1994). Assessing the relationship between industry characteristics and organizational culture: How different can you be? Academy of Management Journal, 37(3), 522-553. http://dx.doi.org/10.2307/256699

Chiesa, V., Coughlan, P., \& Voss, C. A. (1996). Development of a technical innovation audit. Journal of Product Innovation Management, 13, 105-136. http://dx.doi.org/10.1016/0737-6782(95)00109-3

Cohen, J. (1988). Statistical power analysis for the behavioral sciences. Hillsdale, NJ: Erlbaum Associates.

Cohen, J., \& Cohen, P. (1983). Applied multiple regression/correlation analysis for the behavioral sciences (2nd ed.). Hillsdale, NJ: Lawrence Erlbaum Associates.

Covin, J. G., \& Miles, M. P. (1999). Corporate entrepreneurship and the pursuit of competitive advantage. Entrepreneurship Theory and Practice, 23, 47-63.

Cowan, R., \& Jonard, N. (2003). The dynamics of collective invention. Journal of Economic Behavior \& Organization, 52, 513-532. http://dx.doi.org/10.1016/S0167-2681(03)00091-X

Damanpour, F. (1991). Organizational innovation: A meta-analysis of effects of determinants and moderators. Academy of Management Journal, 34(3), 555-590. http://dx.doi.org/10.2307/256406

Damanpour, F. (1996). Organizational complexity and innovation: Developing and testing multiple contingency models. Management Science, 42, 693-716. http://dx.doi.org/10.1287/mnsc.42.5.693

Damanpour, F., \& Schneider, M. (2006). Phases of the adoption of innovation in organizations: Effects of environment, organization and top managers. British Journal of Management, 17, 215-236. http://dx.doi.org/10.1111/j.1467-8551.2006.00498.x

Deal, T. E., \& Kennedy, A. A. (1982). Corporate cultures. Reading, MA: Addison-Wesley.

Delaney, J. T., Jarley, P., \& Fiorito, J. (1996). July. Planning for change: Determinants of innovation in U.S. national unions. Industrial and Labor Relations Review, 49(4), 597-614. http://dx.doi.org/10.2307/2524512

Dess, G. G., \& Robinson, R. B. (1984). Measuring organizational performance in the absence of objective measure: The case of the privately held firm and the conglomerate business entity. Strategic Management Journal, 5, 265-273. http://dx.doi.org/10.1002/smj.4250050306

DeTienne, D. R., \& Koberg, C. S. (2002). The impact of environmental and organizational factors on discontinuous innovation within high-technology industries. IEEE Transactions on Envineering Management, 49(4), 352-364. http://dx.doi.org/10.1109/TEM.2002.806719

Dillman, D. A. (1978). Mail and telephone surveys: The total design method. New York: Wiley. 
Edgar S. F. (1998, 2000). Ward's Business Directory of U.S. Private and Public Companies. Detroit, MI: Gale Research.

Haunschild, P., \& Miner, A. (1997). Modes of interorganizational imitation: The effects of outcome salience and uncertainty. Administrative Science Quarterly, 42, 472-500. http://dx.doi.org/10.2307/2393735

Herring, S., \& Galagan, P. (2011). Why innovation? Why now? T+D, September, 26-28.

Hopkins, W. E., Hopkins, S. A., \& Mallette, P. (2005). Aligning Organizational Subcultures for Competitive Advantage. New York: Basic Books.

Jennings, D. F., \& Lumpkin, J. R. (1992). Insights between environmental scanning activities and Porter's generic strategies: An empirical analysis. Journal of Management, 18(4), 791-803. http://dx.doi.org/10.1177/014920639201800411

Kahn, A., \& Manopichetwattana, V. (1989). Innovative and noninnovative small firms: Types and characteristics. Management Science, 35, 597-606. http://dx.doi.org/10.1287/mnsc.35.5.597

Kaiserfeld, T. (2005). A review of theories of invention and innovation. CESIS Electronic Working Paper Series, Paper No. 47.

Kessler, E. H., \& Chakrabarti, A. K. (1996). Innovation speed: A conceptual model of context, antecedents, and outcomes. Academy of Management Review, 21(4), 1143-1191.

Kilman, R. H. (1985). Corporate culture. Psychology Today, 62-68.

Kimberly, J. (1981). Managerial innovation. In P. Nystrom \& W. Starbuck (Eds.), Handbook of organizational design, 1, 53-97. Oxford University Press.

Klein, L. J., \& Sorra, J. S. (1996). The challenge of innovation implementation. Academy of Management Review, 21(4), 1055-1080.

Koberg, C. S., DeTienne, D. R., \& Heppard, K. (2003). An empirical test of environmental, organizational, and process factors affecting incremental and radical innovation. The Journal of High Technology Management Research, 14(1), 21-45. http://dx.doi.org/10.1016/S1047-8310(03)00003-8

Koberg, C. S., Uhlenbruck, N., \& Sarason, Y. (1996). Facilitators of organizational innovation: The role of life-cycle sage. Journal of Business Venturing, 11(2), 133-150. http://dx.doi.org/10.1016/0883-9026(95)00107-7

Korth, K. (2005). The importance of innovation and new product development. Automotive Design and Production, January, 18-19.

Latour, B. (1996). Aramis or the Love of Technology. Cambridge, MA: Harvard University Press.

Legnick-Hall, C. A. (1992). Innovation and competitive advantage: What we know and what we need to learn. Journal of Management, 18(2), 399-429. http://dx.doi.org/10.1177/014920639201800209

Leonard, D. (1995). Wellsprings of knowledge: Building and sustaining the sources of innovation. Boston, MA: Harvard Business School.

McGinnis, M., \& Ackelsberg, M. (1983). Effective innovation management: Missing link in strategic planning. Journal of Business Strategy, 4, 59-66. http://dx.doi.org/10.1108/eb039007

Miles, M., \& Huberman, A. M. (1994). Focusing and bounding the collection of data: Qualitative data analysis. Thousand Oaks: Sage.

Miller, D., \& Friesen, P. H. (1980). Momentum and revolution in organizational adaptation. Academy of Management Journal, 23, 591-614. http://dx.doi.org/10.2307/255551

Miller, D., \& Friesen, P. H. (1982). Innovation in conservative and entrepreneurial firms: Strategic momentum. Strategic Management Journal, 3, 1-25. http://dx.doi.org/10.1002/smj.4250030102

More, R. (2011). What is success in innovation? Ivey Business Journal, 75(4), 1-6.

Muffatto, M., \& Panizzolo, R. (1996). Innovation and product development strategies in the Italian motorcycle industry. Journal of Product Innovation Management, 13(4), 348-361. http://dx.doi.org/10.1016/S0737-6782(96)00034-3

Murphy, G. Trailer, J., \& Hill, R. (1996). Measuring performance in entrepreneurship research. Journal of Business Research, 36, 15-23. http://dx.doi.org/10.1016/0148-2963(95)00159-X 
Needleman, S., O’Connell, V., Maltby, E., \& Loten, A. (2011). And the most innovative entrepreneur is.... The Wall Street Journal, November 14, R. 1.

O'Reilly, C. A., \& Chatman, J. A. (1996). Culture as social control: Corporations, culture and commitment. In Staw B. M., \& Cummings L. L. (Eds.), Research in organizational behavior, 18, 157-200. Greenwich, CT: JAI Press.

Oster, S. M. (1994). Modern competitive analysis (2nd ed.). New York: Oxford University.

Peace, D. (2011). Strategies for success in product innovation. Retrieved from www.industryweek.com

Scott, S. G., \& Bruce, R. A. (1996). Determinants of innovative behavior: A path model of individual innovation in the workplace. Academy of Management Journal, 37(3), 580-607. http://dx.doi.org/10.2307/256701

Sorensen, J. B. (2002). The strength of corporate culture and the reliability of firm performance. Administrative Science Quarterly, 47(1), 70-91. http://dx.doi.org/10.2307/3094891

Spencer, A. (2012). Analysis: Avoiding innovation's terrible toll. The Wall Street Journal, January 7, B. 1.

Stimpert, J. L. (1992). Managerial thinking and large diversified firms. Unpublished doctoral dissertation, University of Illinois at Urbana-Champaign.

Sykes, H. B., \& Block, Z. (1989). Corporate venturing obstacles: Sources and solutions. Entrepreneurship Theory \& Practice, 4, 159-167.

Tornatzky, L., Eveland, J., Boylan, M., Hetzner, M., Johnson, E., Roitman, D., \& Schneider, J. (1983). The processes of innovation: Analyzing the literature. Washington, D.C.: National Science Foundation.

Utterback, J. M., \& Abernathy, W. J. (1975). A dynamic model of process and product innovation. Omega, 3, 639-656. http://dx.doi.org/10.1016/0305-0483(75)90068-7

Van de Ven, A. (1986). Central problems in the management of innovation. Management Science, 32, 590-607. http://dx.doi.org/10.1287/mnsc.32.5.590

Van de Ven, A. H., Polley, D. E., Garud, R., \& Venkataraman, S. (1999). The innovation journey. New York: Oxford University.

Woodman, R. W., Sawyer, J. E., \& Griffin, R. W. (1993). Toward a theory of organizational creativity. Academy of Management Review, 18(2), 293-321.

Zahra, S., \& Covin, J. (1995). Contextual influences on the corporate-entrepreneurship-performance relationship: A longitudinal analysis. Journal of Business Venturing, 10, 43-58. http://dx.doi.org/10.1016/0883-9026(94)00004-E

Zaltman, G., Duncan, R., \& Holbek, J. (1973). Innovations and organizations. New York: Wiley-Interscience.

Ziger, B. J., \& Maidique, M. (1990). A model of new product development: An empirical test. Management Science, 36, 867-883. http://dx.doi.org/10.1287/mnsc.36.7.867 